\title{
O ERRO COMO MEIO DE PRODUÇÃO DE CONHECIMENTO: MAX WEBER E A ENTWICKLUNGSGESCHICHTE
}

\author{
O mundo não nos importa \\ O nosso mundo começa \\ Cá dentro da nossa porta. \\ Joaquim Pimentel \\ (fadista português)
}

O fato de cientistas da mais alta extração não estarem isentos de erros que se afiguram como bizarros aos olhos de gerações posteriores é bem conhecido na história da ciência. Pasteur, por exemplo, supunha, até 1880, que a imunidade resultava do esgotamento dos nutrientes essenciais de que a bactéria necessita para se multiplicar no organismo em que se hospeda. Esta concepção, conhecida como "teoria da depleção", tornou-se alvo de galhofa quando se descobriu, poucos anos depois, que vacinas feitas com bacilos de cólera mortos eram tão eficazes quanto as feitas com organismos vivos. Um pouco mais tarde, o bacteriologista alemão Robert Koch, cuja estatura como homem de ciência rivaliza com a de Pasteur, notou a presença do bacilo anthrax dentro de leucócitos de animais doentes e concluiu, para o escárnio das gerações posteriores, que o leucócito era o meio em que a bactéria penetra, se multiplica e do qual se utiliza para se alojar-se nos diferentes órgãos.

O pensamento sociológico, ao que parece, não fornece exemplos de erros tão anedóticos. Não obstante, neste artigo quero chamar a atenção para uma concepção sociológica cujo caráter bizarro não escapou aos historiadores e eruditos. Refiro-me ao conceito de povo-pária, tal como Weber o formulou, isto é, como chave para a compreensão do comportamento dos judeus enquanto minoria étnica e religiosa. Apesar de a literatura especializada ter mostrado, nos últimos cinquenta anos, a inadequação teórica e empírica deste conceito sob os mais diferentes ângulos, ${ }^{1}$ na literatura sociológica ele tem sido retido como um meio de explicar a incompatibilidade última entre o judaísmo e o desenvolvimento do racionalismo ocidental. Assim, em seu aclamado livro The rise of western rationalism, o sociólogo alemão Wolfgang Schluchter argumenta que embora a doutrina profética hebraica tenha dado início ao processo de racionalização da conduta no Ocidente (ao conceber um Deus único e pessoal que faz demandas 
éticas), o fato de os judeus terem se transformado (após a experiência do exílio babilônico) em um povo pária impediu que a referida doutrina ganhasse uma dinâmica universalista, problema que viria a ser solucionado posteriormente com o advento do cristianismo (Schluchter, 1981: 152). ${ }^{2}$ Em um trabalho posterior, ele se mostra ciente de que o conceito de povo-pária é alvo de merecidas críticas (Schluchter, 1989), ${ }^{3}$ mas faz duas ressalvas: esse conceito é importante para explicar por que os judeus não criaram o espírito do capitalismo e para realçar a condição "marginal" dos judeus, em contraste com a posição "heterodoxa" dos protestantes. Mais recentemente, Schluchter (2004) mencionou a inadequação do conceito de povo-pária quando aplicado ao judaísmo na Antiguidade, mas, ainda assim, argumentou que é importante retê-lo (aplicado à Antiguidade) porque sem ele a abordagem mais abrangente de Weber a respeito do desenvolvimento do racionalismo Ocidental perderia parte de seu apelo.

Neste artigo discuto a pertinência de toda essa linha de argumentação. Na seção 1 passo em revista as implicações que Weber extraiu de seu conceito de povo-pária e procuro mostrar que nenhuma delas se sustenta. Na seção 2 discuto especificamente a tese de Schluchter de que o conceito de povo-pária ajuda a entender por que os judeus não criaram o espírito do capitalismo. $\mathrm{Na}$ seção 3 detenho-me no esforço de Schluchter em reter o conceito de povo-pária apesar de reconhecer sua inadequação empírica. Argumento que esse esforço somente conduziu a erros adicionais.

Antes de iniciar a discussão devo, entretanto, ressaltar que há circunstâncias em que concepções sabidamente equivocadas, ou mesmo disparatadas, podem cumprir um papel relevante no desenvolvimento científico. Um exemplo disto nos é oferecido por Karl Popper, em seu Objective knowledge. Galileu supunha equivocadamente que a Lua não tinha influência sobre as marés. No contexto em que foi produzido, argumenta Popper, esse equívoco foi importante para que se chegasse a uma explicação estritamente mecânica (isto é, sem influência da astrologia) dos movimentos dos planetas, a qual, por sua vez, foi importante para a posterior formulação das leis da inércia e da correspondente lei de conservação para os movimentos rotativos (Popper, 1992: cap. 4, seção 9). Erros bizarros não devem, portanto, ser tão prontamente varridos para o "lixo de entulhos da história" - para me valer de uma feliz expressão de Paul Feyerabend (1993). Mas, será este o caso da concepção weberiana de povo-pária? 
De tempos em tempos alguma perspectiva metateórica cai em desgraça no pensamento sociológico enquanto outras, ao contrário, irrompem com tamanha autoridade que o simples ato de adotá-las parece ser suficiente para dissipar qualquer possível objeção. Nas últimas décadas, uma abordagem que ficou conhecida como "desenvolvimental" (ou "histórico-desenvolvimental" - Entwicklungsgeschichte) tem roubado a cena no pensamento sociológico. ${ }^{4}$ Uma entusiasmada defesa dessa perspectiva foi feita no início dos anos de 1980 por Holton nos seguintes termos:

Ao que parece, nada retrata melhor a perspectiva de Weber do que sua atitude crítica em relação às teorias evolucionistas de mudança social. Sua epistemologia neo-kantiana, de acordo com a qual o curso da "história" é inerentemente sem sentido, levou-o a resistir a explicações evolucionistas do desenvolvimento do capitalismo, as quais, como no caso do marxismo do final do século XIX, pressupunha algum tipo de desdobramento da história em direção a um fim geral predeterminado. Ao mesmo tempo, entretanto, isto não o impediu de aceitar a noção de história desenvolvimental (Entwicklungsgeschichte). Esta alternativa ao evolucionismo lhe permitiu descrever a lógica do racionalismo moderno e, em termos mais gerais, da racionalização, ao mesmo tempo em que deixou espaço para a análise do complexo desenvolvimento histórico em termos, não de necessidade histórica, mas dos aspectos contingentes da sociedade ocidental (Holton, 1983:170).

O entusiasmo de Schluchter pela Entwicklungsgeschichte não é menor: "somente através de uma perspectiva desenvolvimental", ele diz, "podemos identificar as ações sociais que têm consequências decisivas para configurações sociais básicas. Somente dessa forma podemos distinguir eventos que transcendem uma dada estrutura de eventos que a preservam, eventos que levam à transformação dos que permanecem nos limites de uma dada estrutura" (Schluchter, 1981: 176). ${ }^{5}$

O autor não poderia ter sido mais claro: não há conhecimento histórico-cultural digno do nome fora da Entwicklungsgeschichte - da abordagem "histórico-desenvolvimental”, para a qual "o que está em jogo é sempre um desenvolvimento histórico particular, cuja reconstrução se dá em três estágios: identificação (quais são as características que definem uma dada manifestação cultural?), atribuição causal (como essas características surgem?) e priorização (que peso deve ser dado a um fator causal em relação a outros?)" (Schluchter, 2004: 44). A primeira pergunta, esclarece ele, só pode ser respondida mediante comparação; esclarece também como as outras duas podem ser respondidas, mas isto não nos importa aqui (Schluchter, 2004: 44).

Dado que, para o autor, a reconstrução do processo mais abrangente de desenvolvimento do racionalismo ocidental demanda a retenção do conceito weberiano de povo-pária (ponto ao qual retorno na seção 3), e dado que é no estudo de Weber sobre o judaísmo antigo (refiro-me ao livro Ancient Judaism, ainda não traduzido para o português) que esse conceito adquire uma importância crucial, Schluchter se detém nesse estudo. Ele o considera "particularmente adequado 
para lançar luz sobre a [...] orientação comparativa e desenvolvimental" de Weber (Schluchter, 2004: 33). Com efeito, é em Ancient Judaism que está dito:

\begin{abstract}
De um ponto de vista sociológico, os judeus eram um povo pária, o que significa, como sabemos através da Índia, um povo hóspede, ritualmente separado, formalmente ou de fato, de seu entorno social. Todas as características essenciais da atitude dos judeus em relação ao seu meio podem ser deduzidas de sua existência pária - especialmente seu gueto voluntário, que em muito antecedeu o confinamento compulsório, e a natureza dual de sua moralidade: um padrão para os de dentro, outro para os de fora (Weber, 1952: 3, grifos meus).
\end{abstract}

Há que se reconhecer que, em Ancient Judaism, Weber observou mesmo os "três estágios" descritos por Schluchter. No "estágio 1", recapitulemos, trata-se de identificar, via comparação, as características que definem uma dada "manifestação cultural" - no caso em consideração, o judaísmo pré-talmúdico. Weber o fez: a comparação com o caso hindu levou-o a conceituar, logo de saída, os judeus como um "povo-pária" e "deduzir", a partir daí, que as características que os definem são as mesmas que definem qualquer "povo pária". Para além das mencionadas segregação ritualística ("gueto voluntário") e "moralidade dual", os judeus, "povo pária" que eram, se caracterizavam (assim Weber "deduziu") pela tendência a perseverar na condição de pária quando sob ameaça externa e pela propensão para o "capitalismo aventureiro" ou "especulativo" (em oposição ao “capitalismo racional", peculiar aos tempos modernos). No "estágio 2", trata-se de mostrar o modo como essas características surgiram. Mais uma vez, Weber o fez, ao dedicar uma seção inteira de seu Ancient Judaism ao "desenvolvimento da segregação ritualística" dos judeus e outra ao surgimento da "moralidade dual" judaica. ${ }^{6}$ Finalmente, no "estágio 3", cumpre discutir o peso de diferentes fatores causais na produção dessas características. Pela terceira vez, Weber o fez: o fator destacado por ele, nas páginas finais de Ancient Judaism, foram as "promessas messiânicas únicas", peculiares à doutrina profética hebraica. Em todos os três "estágios" a noção do judeu como um "povo-pária" circula livremente, sem ser perturbada por nenhum tipo de demanda.

Sem o salvo-conduto concedido pela Entwicklungsgeschichte, entretanto, o conceito weberiano de povo-pária não teria uma vida tão fácil. Nesse caso, tornar-se-ia imperativo investigar se as características ditas "definidoras" do judaísmo, deduzidas a partir deste conceito, são, de fato, definidoras de alguma coisa. ${ }^{7}$ Em um trabalho anterior recorri à ajuda dos historiadores para mostrar que, ao contrário do que Weber supunha, por toda a Antiguidade e Idade Média o cristianismo, não menos que o judaísmo, era assombrado pelo fantasma da “contaminação" interétnica via comensalidade e conúbio (ver Freitas, 2010: cap. 2). ${ }^{8}$ A veemência e recorrência com que por mais de um milênio os cânones disciplinares dos Concílios da Igreja proibiam a comensalidade e o conúbio entre cristãos e judeus indicam que havia entre ambos um intercâmbio social muito mais estreito do que o conceito de "povo-pária" pode nos levar a supor. ${ }^{9}$ 
Se Weber se equivocou ao sustentar que os judeus na Antiguidade se caracterizavam pela tendência à autossegregação, da mesma forma ele se equivocou ao postular que os judeus, em razão de sua "existência pária", autoimposta, orientavam sua conduta por uma "ética dual". Weber baseou sua atribuição de uma ética dual ao judaísmo ao que se lê em Deuteronômio 23:20: "ao estrangeiro emprestarás com juros, porém a teu irmão não emprestarás com juros”. Ele deduziu deste versículo que os judeus preservaram o antigo dualismo ético tribal, padronizado na injunção de proibir o empréstimo de dinheiro a juros ao irmão tribal, mas permitir que se o fizesse ao estrangeiro (ver Oelsner, 1962: 195). Ora, nem tudo o que está escrito no Pentateuco está necessariamente no DNA do judaísmo, mesmo porque o Pentateuco é uma obra de muitas camadas e muitas vezes algo que aparece em camadas mais antigas não reaparece, ou mesmo é contraditado, pelo que aparece nas camadas mais tardias. Apesar de sua assombrosa erudição, talvez Weber ignorasse o fato de o Deuteronômio ter sido o primeiro livro (de que se tem notícia) a proibir o empréstimo a juros. Ao fazer do estrangeiro uma exceção, buscava-se evitar que estrangeiros que emprestavam a juros explorassem os judeus (Shmuelli, 1968: 190). No período dominado pelos Aaronitas, ${ }^{10}$ descrito em Números, o livro mais tardio do Pentateuco, esta injunção já não aparece e, posteriormente, nos tempos talmúdicos, a literatura rabínica criticou severamente o versículo em questão a ponto de fazer com que não se aceitasse, nos tribunais, a palavra de quem emprestava dinheiro, quer a judeus ou a gentios (Oelsner, 1962: 196). Por outro lado, há que se dizer que entre os cristãos, a quem Weber credita o feito de ter rompido com a ética dual judaica, havia injunções rigorosamente idênticas à do versículo do Deuteronômio. Assim, a historiadora Toni Oelsner chama a atenção para o fato de que em dois pacis Bavaricae sucessivos, de 1244 e 1256, havia cláusulas proibindo os cristãos de emprestar a juros, ou contra penhora, exceto aos judeus. Isto, salienta ela argutamente, "está exatamente de acordo com a fórmula da ética dual, que Weber supunha ser peculiar à presumida atitude pária dos judeus" (Oelsner, 1962: 198).

Quando, por outro lado, examinamos as diásporas judaicas, a inadequação do conceito de povo-pária torna-se ainda mais patente. O caso sefardita é exemplar. Se nos voltamos para o processo que culminou na expulsão dos judeus da Espanha, em 1492, o qual teve início com uma conversão em massa ao cristianismo, veremos que esta conversão, longe de ter significado para os judeus, como o pensamento de Weber nos levaria a crer, uma solução para a existência "pária" que eles teriam imposto a si próprios desde o retorno do exílio na Babilônia, foi justamente o acontecimento que os conduziu à condição de pária, pelo menos no sentido de que a partir de então passaram a ser rejeitados tanto pelos judeus que resistiram à onda de conversão quanto pelos cristãos. Assim, o ano de 1391 marca o início da referida conversão em massa (em larga medida voluntária) de judeus ao cristianismo na Espanha e este fato, ao invés 
de implicar a remoção de barreiras étnicas e de nascimento, ou, para tomar uma expressão do próprio Weber em outra de suas obras, o "alívio proporcionado pela consciência de ter escapado ao destino de pária” (Weber, 1965: 259) implicou justamente o reforço dessas barreiras. Longe de facilitar o convívio ou o intercâmbio social entre judeus e cristãos, a contínua conversão dos primeiros acabou criando, para os últimos, o problema de distinguir o "cristão natural" do "converso". Talvez fosse conveniente passar a palavra a Janet Adelman, uma estudiosa do assunto (que nada sabe de Entwicklungsgeschichte):

Na Espanha do século XVI o perigo não era o de que os judeus se mantivessem como uma comunidade isolada que recusasse a graça cristã, mas que pudessem se converter [ao cristianismo] e infiltrar na sociedade espanhola em todos os níveis, tornando-se indistinguíveis dos seus hospedeiros espanhóis na medida em que ocupassem as posições dominantes, pois a conversão punha em risco os sinais mais confiáveis de diferença, provocando uma crise em uma sociedade muito miscigenada e obsessivamente preocupada com a pureza da linhagem (Adelman, 2003: 11). ${ }^{11}$

Essas considerações mostram o quanto Schluchter errou o alvo ao caracterizar, em uma de suas obras, a posição dos judeus como intrinsecamente "marginal", em contraste com a posição intrinsecamente "heterodoxa" do ascetismo protestante. "Um movimento heterodoxo", ele diz, "se distingue de um movimento marginal não apenas por se dirigir para o centro, mas por ter a possibilidade objetiva de penetrar neste centro. Ele combina alta capacidade de inovação e alta capacidade de difusão" (Schluchter, 1989: 199). Ora, os judeus foram expulsos da Espanha exatamente por exibir a "alta capacidade de difusão" que Schluchter afirma não poder haver entre eles, por conta de sua condição intrinsecamente (pois derivada de sua alegada condição "pária") "marginal". A posição "heterodoxa" do protestantismo ascético, em contraste, teria permitido (assim assevera Schluchter) não só que este "inovasse", produzindo o "espírito do capitalismo", como também "difundisse" esse "espírito" no "centro" não-protestante. A pertinência dessa tese, isto é, dessa atribuição de um caráter inovador ao protestantismo ascético, será detidamente discutida na próxima seção.

Antes, entretanto, vejamos a terceira característica que Weber atribui ao "povo pária judeu": a tendência a perseverar na condição de pária. Talvez a melhor maneira de descrever o modo como Weber atribui essa característica aos judeus seja mostrar o modo como ele se ancora no conceito de povo-pária para comparar a posição dos judeus com a dos hindus:

O judaísmo, tanto em sua forma exílica quanto pós-exílica, oferece uma importante ilustração do significado do conteúdo das promessas religiosas. Desde o Exílio, de fato e, formalmente, desde a destruição do Templo, os judeus se tornaram um povo-pária [...], isto é, um grupo que se tornou uma comunidade hereditária à parte, ao qual falta uma organização política autônoma e caracterizado por proibir a comensalidade e por basear o matrimônio em injunções mágicas, tabuísticas e 
rituais. Duas características adicionais de um povo-pária são o desprivilégio político e social, e uma atividade econômica peculiar. Certamente, o povo-pária da Índia, as castas hindus desprivilegiadas e ocupacionalmente especializadas, assemelham-se aos judeus nesse particular, uma vez que o status pária de ambos também envolve segregação em relação ao mundo externo como um resultado de tabus, obrigações religiosas hereditárias na condução da vida e a associação da esperança de salvação com seu status de pária. Essas castas hindus e o judaísmo mostram os mesmos efeitos característicos de uma religião pária: quanto mais opressiva a posição na qual os membros de um povo-pária se acha, mais estritamente a religião os faz se voltar uns para os outros e para sua posição de pária, e mais poderosas se tornam as esperanças de salvação que se vinculam ao cumprimento das obrigações religiosas ordenadas por Deus (Weber, 1965: 108-109).

Sugerir, como Weber o faz acima, que "tabus, obrigações religiosas hereditárias na condução da vida e a associação da esperança de salvação com seu status de pária" explicam a segregação a que os judeus têm se sujeitado desde o exílio babilônico é um exemplo extremo de despropósito a que o uso apriorístico do conceito de povo-pária pode conduzir. ${ }^{12}$ Melhor, portanto, desconsiderá-lo. Importa reter, entretanto, que na citação acima a discussão de Weber se passa em um plano prioritariamente conceitual e, embora haja, conforme já mencionei, uma vasta literatura especializada que conteste vigorosamente a concepção de "povo-pária" tal como Weber a formulou, limito-me, aqui, a discutir o que Weber faz a partir dela: ele compara o modo como um "povo-pária" (os judeus) e um não-pária (os cristãos orientais) reagem quando sob o domínio de um terceiro povo (os omíadas). Assim, imediatamente após a passagem acima, Weber continua:

O laço entre Yahweh e seu povo tornou-se tanto mais indissolúvel quanto mais mortal foi a humilhação e a perseguição imposta a ele. Em óbvio contraste com os cristãos orientais, que sob os omíadas afluíram à religião privilegiada do Islã em tão grande número que as autoridades políticas tiveram que dificultar sua conversão para preservar os interesses das classes privilegiadas, todas as frequentes e forçadas conversões em massa dos judeus, que lhes permitiriam obter os privilégios das classes dominantes, resultaram ineficazes. Tanto para os judeus quanto para as castas hindus o único meio de obter salvação era cumprir os preceitos religiosos peculiares a um povo-pária, dos quais não há como se furtar sem atrair consequências maléficas ou sem colocar em risco a sorte futura, seja a própria ou a dos descendentes (Weber, 1965: 109).

O quê mais, se não seu conceito de "povo-pária", pode ter levado Weber a concluir que "todas as frequentes e forçadas conversões em massa dos judeus, que lhes permitiriam obter os privilégios das classes dominantes, resultaram ineficazes"? Certamente não foi uma investigação empírica, pois esta mostraria, conforme mencionei anteriormente, que a conversão em massa dos judeus ocorrida na Espanha a partir de 1391 foi tão "eficaz" que o número de conversos se avolumou a ponto de se virem estigmatizados como portadores de "defeito de sangue". Entretanto, o ponto para o qual quero chamar a atenção é outro: 
nota-se como Weber, uma vez equipado com o conceito de "povo-pária”, torna a investigação empírica irrelevante. Ao constatar que sob o domínio dos omíadas os cristãos orientais, mas não os judeus, se converteram em massa, em vez de se perguntar pelas razões dessa diferença, automaticamente concluiu que os judeus não o fizeram por receio de "atrair consequências maléficas" ou de "colocar em risco a própria sorte ou a de seus descendentes" - afinal, nos marcos da sua "orientação comparativa e desenvolvimental", este receio é próprio de um "povo-pária" e, portanto, o assunto se encerra aí.

Receio, entretanto, que o assunto não possa se encerrar tão facilmente. Weber não considerou a possibilidade de os cristãos orientais (e, mais ainda, os ocidentais) terem tido razões bem mais fortes que os judeus para se converter após o domínio omíada. Durante o domínio omíada no Oriente as relações entre os muçulmanos e os não-muçulmanos eram reguladas pelo pacto de Omar, e este pacto, embora implicasse restrições tanto para os judeus quanto para os cristãos, ${ }^{13}$ significou para os judeus um ganho, pois estes viviam até então sob o jugo cristão, do qual se livraram com a presença omíada e, para os cristãos, uma perda. Para os judeus ele significou o direito de viver e praticar a religião livremente, sem restrições por parte do Estado. Nessas circunstâncias, a conversão era claramente mais vantajosa para os cristãos do que para os judeus. A bem da verdade, as razões pelas quais os cristãos, em contraste com os judeus, se converteram em massa ao islamismo sob o domínio omíada requerem investigação empírica, e não um conceito sociológico, seja o de "povo-pária" ou qualquer outro. Embora investigações históricas não possam, obviamente, ser conduzidas à margem de conceitos, estes não precisam necessariamente ser fornecidos pela sociologia; muito menos podem servir de substituto para a investigação ou de premissa a partir da qual os cursos reais de eventos são deduzidos. ${ }^{14}$

\section{2}

Em um dos excertos acima reproduzidos, Weber afirma que é característico dos povos-pária dedicarem-se a uma "atividade econômica peculiar". No que se refere aos judeus, a "atividade econômica peculiar" pode ser o comércio, a agiotagem, a especulação financeira, a coleta de impostos, enfim, qualquer coisa que não esteja relacionada com a produção industrial em larga escala, a marca distintiva do capitalismo moderno. Weber, como sabemos, supunha que a produção industrial em larga escala, tal como hoje a conhecemos, requereu, pelo menos em seus primórdios, uma atitude mental peculiar; uma dedicação ao trabalho contínuo e disciplinado, concebido como um fim em si mesmo. Esta atitude mental, ele argumentou, faltou aos judeus. A esta predisposição para a disciplina, para a vida metódica, para a acumulação permanente de capital, tomada não como um meio para o enriquecimento, mas como um 
princípio orientador de vida; um dever moral, uma obrigação que se cumpre para a própria satisfação interior; a esta sensação irracional de satisfação pelo dever cumprido ao empregar bem o tempo, ao poupar e multiplicar dinheiro, ao executar corretamente as tarefas do dia a dia, Weber chamou de "espírito do capitalismo". Este "espírito", ele argumentou, faltou aos judeus, aos católicos, aos luteranos, enfim, a toda forma de religiosidade qualitativamente distinta da exibida pelo protestantismo ascético. E, por subscrever tudo isto, Schluchter se sentiu à vontade para afirmar que é pertinente caracterizar os judeus como um povo-pária porque, não obstante a "inexatidão histórica" desse conceito, e o fato de ele não estar livre de "conotações ideológicas", assim procedendo podemos responder a seguinte pergunta: "por que os judeus não produziram o 'espírito' do capitalismo moderno?” (Schluchter, 1989: 199).

Evidentemente, o autor só faz esta pergunta porque pressupõe que o protestantismo ascético produziu o "espírito do capitalismo moderno", tal como Weber o concebeu. Examinemos, então, este pressuposto. Para Weber, como sabemos, essa disposição mental que ele chamou de o "espírito do capitalismo" é, em sua origem, um resultado do sentimento psicológico de ansiedade advindo da incerteza quanto à salvação, o qual, por sua vez, resulta, fundamentalmente, da doutrina calvinista da predestinação. Diferentemente de um católico ou um judeu, o asceta protestante não pode buscar a salvação de sua alma simplesmente contabilizando suas "boas obras". Pior que isto, ele nada pode fazer para alterar o destino de sua alma, pois este já se acha predeterminado. Entretanto, ele pode aliviar sua ansiedade tomando conhecimento, de antemão, daquilo que lhe foi reservado. O sucesso na condução de seus assuntos mundanos, resultante de uma vida regrada, é a prova de sua predestinação à salvação eterna. Seu sucesso neste mundo é a prova de seu sucesso no outro mundo. Daí, o autocontrole, a disciplina e a industriosidade característicos do empreendimento racional capitalista moderno.

Esta associação que Weber estabelece entre a ansiedade oriunda da incerteza em relação à salvação (ela própria um resultado da doutrina da predestinação) e a predisposição para o padrão de conduta acima descrito é, sabidamente, muito contestada na literatura histórica e erudita especializada. O historiador Trevor-Roper, por exemplo, argumenta que nada há de particularmente protestante ou calvinista na disciplina mental e moral que Weber atribui, corretamente em sua opinião, ao homem moderno. Esta disciplina, ele diz, é uma herança do pensamento de Erasmo, do qual Calvino se serviu para pregar o retorno ao cristianismo primitivo, o estudo da Bíblia, a santificação da vida leiga e, sobretudo, a dedicação incondicional ao trabalho como forma superior de devoção religiosa. Especialmente este último item, que Weber supunha ser o próprio cerne da "ética protestante", já era disseminado entre praticantes católicos "erasmianos" antes da Reforma (Trevor-Roper, 2007: 54). Este argumento é consistente com três outros, vindos de direções bem diversas. 
Ele é consistente, em primeiro lugar, com o que os próprios dogmatistas do século XVII diziam a respeito da doutrina calvinista da predestinação: que se tratava apenas de uma concepção dogmática dos eruditos, abstrata demais para exercer qualquer influência significativa sobre a conduta cotidiana dos devotos (Graf, 1993: 39). Em segundo lugar, ele é consistente com a constatação de que o calvinismo passou, desde sempre, por profundas transformações doutrinárias (ver, por exemplo, MacKinnon, 1988: 169). Essas se iniciaram ainda antes da morte de Calvino e, menos de um século mais tarde, em Westminster ${ }^{15}$ estabeleceu-se que "a salvação não estava mais oculta pelo véu divino, mas iluminada para todos os que estivessem determinados a agarrá-la." (MacKinnon, 1988: 169). O calvinismo, esclarece MacKinnon, "chegou a esta posição evoluindo como um híbrido, absorvendo elementos tanto do catolicismo quanto do luteranismo." (MacKinnon, 1988: 169). Para os propósitos da presente discussão é suficiente mencionar que o calvinismo absorveu do catolicismo a noção de justificação pelas obras e, nesse sentido, está longe de desfrutar da especificidade (ou do caráter único) que Weber lhe atribuiu. Tanto quanto um católico, ou um judeu, um calvinista do século XVII poderia interferir sobre o destino de sua alma. Ele o faria, quer contabilizando suas "boas obras", a exemplo dos católicos, quer, à maneira dos luteranos, por uma diligência espiritual que deles fizesse um "recipiente" sobre o qual o Espírito Santo derrama o discernimento necessário para o reconhecimento da fé verdadeiramente redentora.

Em terceiro lugar, tudo isto é compatível com o fato de que, para toda uma geração de pregadores protestantes da virada do século XVI para o XVII, a reforma da doutrina cristã, tal como realizada por Lutero e Calvino, deveria ser seguida por uma segunda reforma, "a reforma da vida", e nada servia melhor a este propósito do que a produção em massa de tratados devocionais, os quais eram escritos, impressos e vendidos não às dúzias, mas às centenas e aos milhares. O ponto a ser destacado é que, para os autores desses tratados, os limites confessionais eram praticamente irrelevantes, pois os calvinistas se valiam de escritos luteranos e vice-versa; ambos, por seu turno, valiam-se de fontes católicas do medievo tardio (ver Lehmann, 1987: 314-315). Não espanta, portanto, que o calvinismo tenha incorporado a noção de salvação pela contabilização das boas obras, que Weber supunha peculiar aos "tradicionalismos" católico e judaico.

Diante de tudo isto, fica extremamente difícil sustentar, como o pensamento weberiano o faz, a existência de um fosso teológico entre o calvinismo (onde o homem é visto estritamente como um "instrumento" de Deus e não se admite qualquer concepção "contábil" de salvação) por um lado, e o luteranismo (onde o homem pode ser visto como um "recipiente" de Deus) e o catolicismo (onde o homem é visto como um instrumento, mas pressupõe-se uma concepção "contábil" da salvação), por outro. É verdade que a Entwicklungsgeschichte demanda a existência desse fosso, mas nem sempre a vida real pode 
satisfazer as suas demandas. Receio que a vida real tenha contrariado a demanda de que o protestantismo, em sua versão ascética, tenha produzido esta atitude mental peculiar que Weber chamou de "o espírito do capitalismo" - ou a de que a Reforma logrou realizar uma mudança qualitativa de mentalidade, uma "transformação da alma do homem", como diz o próprio Weber (2003: 368), sem a qual o capitalismo não poderia ter se desenvolvido da forma como o fez.

Para explicar melhor o que estou chamando de "vida real" vou retomar uma polêmica que, passados 30 anos, mantém ainda seu interesse. Refiro-me ao debate ocorrido entre Cohen e Holton, no início dos anos de 1980 (mesma época em que Schluchter publicava seu The rise of western rationalism), a respeito do papel do ascetismo intramundano protestante no desenvolvimento do capitalismo moderno (Cohen, 1980; Holton, 1983). Cohen procurou mostrar que todas as características, sem exceção, que o próprio Weber atribuiu ao capitalismo moderno já existiam nos empreendimentos capitalistas anteriores à Reforma. Já na Itália medieval, Cohen argumentou, as empresas funcionavam nos moldes das organizações burocráticas modernas, já conhecendo o livro-caixa (o próprio Weber, diga-se de passagem, estava ciente disto), ${ }^{16}$ o balancete, a separação entre a casa e a unidade de produção, o uso racional do tempo e a produção de mercadorias para um círculo abstrato de consumidores (Cohen, 1980). Curiosamente, mais de uma década antes, Trevor-Roper já havia dito a mesma coisa de uma forma que vale a pena reproduzir:

As empresas de Benedetto Zacaria em Gênova, de Roger Boinebroke em Gante [ambas do século XIII], dos grandes comerciantes de tecidos e banqueiros de Florença eram tão "racionais" em seus métodos, quanto "burocráticas" em sua estrutura, como qualquer capitalismo moderno; e se os criadores dessas empresas eram às vezes personagens chocantes - "capitalistas aventureiros judeus" mais do que "ascetas mundanos" - assim (como agora achamos) eram os calvinistas De Geer e De Witte do século XVII (Trevor-Hoper, 2007: 51).

De Geer e De Witte, cabe esclarecer, eram os maiores empreendedores capitalistas da Europa da primeira metade do século XVII, e o estilo de empreendedorismo de ambos, como também de todos os outros grandes empreendedores calvinistas do século XVII, em nada se distinguia do estilo "aventureiro", ou "pária", que Weber supunha peculiar aos empreendedores judeus. ${ }^{17}$ Por outro lado, em se tratando do tema em consideração, não podemos nos furtar a ouvir Fernand Braudel:

Vendo hoje, retrospectivamente, não se poderia negar que o capitalismo ocidental tenha fabricado, com o tempo, uma nova arte de viver, novas mentalidades, que ele acompanha e é acompanhado por elas. [...] Mas, enfim, se houve mudança, data de quando? Max Weber quer que seja a partir do protestantismo [...]; Werner Sombart, a partir da Florença do século XV. [...] Na minha opinião, não há dúvidas: Sombart tem razão neste ponto. Florença, já no séc. XIII, a fortiori no século XV, é uma cidade capitalista, seja qual for o sentido que se dê a esta palavra (Braudel, 2009: 515). 
Nessa perspectiva, o advento do capitalismo racional moderno teria sido, sobretudo, o resultado da generalização de um padrão de empreendimento econômico já existente; ele teria sido, como sugeriu o próprio Cohen, "a culminação de um processo longo e gradual", que teve início com empreendimentos econômicos como os acima citados. Posto que uma conclusão de tal natureza contraria os princípios da Entwicklungsgeschichte, uma vez que esta última demanda a existência de "imagens de mundo" que, tal como "agulheiros" (para retomar uma das mais conhecidas metáforas de Weber), apontam de tempos em tempos para novas (e inesperadas) direções para o desenvolvimento histórico, Holton, ao polemizar com Cohen, se prontifica a descartá-la, evocando, para tanto, não alguma evidência empírica, mas o fantasma do evolucionismo:

Embora Cohen não utilize explicitamente a perspectiva evolucionista, ele se aproxima disto ao invocar uma teoria Whig da emergência do capitalismo em contraposição a Weber. A teoria Whig apresenta épocas históricas passadas (como a Renascença) meramente como um estágio conduzindo ao presente. Assim, imagina-se que um "longo [...] processo histórico de desenvolvimento" culminou no "sistema final" (Cohen 1980, p. 1350). Para Weber, em contraste, o capitalismo anterior à Reforma não pode ser considerado um estágio inicial no desenvolvimento "sempre para a frente e sempre para a cima" do capitalismo moderno. Ele não tem uma dinâmica interna que o conduz ao sistema moderno. É essa perspectiva antievolucionista que explica as reservas de Weber em relação ao significado desenvolvimental da economia da Renascença (Holton, 1983: 170).

Nota-se que essa contestação ao argumento de Cohen (e, por implicação, aos argumentos de Braudel e Trevor-Roper) é uma petição de princípio: afirma-se que o capitalismo renascentista não pode ter tido "uma dinâmica interna" que o conduzisse, de forma lenta e gradual, ao capitalismo moderno, porque à luz da perspectiva "antievolucionista", "desenvolvimental”, de Weber, um desenvolvimento de tal natureza é por definição inconcebível. Holton faz daquilo que é tão somente a sua premissa, a saber, que o capitalismo moderno é de natureza distinta do capitalismo da Renascença, a sua conclusão. Para que sua refutação do argumento de Cohen fosse mais que uma mera afirmação de fé na superioridade da Entwicklungsgeschichte, seria necessário mostrar que, para além das características que Cohen listou como distintivas do capitalismo italiano medieval e renascentista, alguma novidade, não mencionada por ele, surgiu no capitalismo moderno em decorrência da Reforma e, mais do que isto, que justamente essa novidade seria o que o faz "racional" e "moderno".

Nessa perspectiva, torna-se imperativo mostrar que novidade teria escapado a Cohen, isto é, que novidade essa disposição mental chamada "o espírito do capitalismo" teria introduzido no empreendimento capitalista pós-Reforma de modo a distingui-lo qualitativamente do anterior. Afirmar, como Holton o faz (1983: 168), que a novidade introduzida foi tornar a busca do lucro um "princípio orientador da vida" e um "fim em si mesmo" não resolve o problema, a menos 
que se mostre quando e como essa alegada novidade conferiu ao empreendimento capitalista uma nova feição.

Dessa forma, admitindo-se que o capitalismo moderno apresenta alguma novidade em relação ao medieval ou ao renascentista, a Entwicklungsgeschichte não tem se revelado um bom caminho para nos conduzir a ela. Os historiadores que o digam. Braudel, por exemplo, recorre extensivamente à obra The first industrial nation [A primeira nação industrial], do historiador inglês Peter Mathias, para mostrar que é somente a partir do final do século XVIII que o capitalismo adquire, de fato, uma nova feição. Somente nessa época surge um personagem verdadeiramente novo, a saber, o industrial propriamente dito, que "rompeu um a um todos os vínculos" entre a então existente pré-indústria e o capitalismo mercantil. O surgimento dos industriais constitui uma novidade na medida em que esses, nas palavras do próprio Braudel, "tendem a se desvencilhar do intermediário, que é o mercador, e passar eles próprios a controlar a compra e colocação da matéria-prima, sua qualidade, sua regularidade. Desejosos de vender muito, querem estar à altura, querem conhecer por si próprios os movimentos do mercado e de se adaptar a eles." (Braudel, 2009: 553-554).

Assim, os Fieldens, donos de uma fiação de algodão no início do século XIX, confiavam a compra da matéria-prima a seus próprios agentes, que enviavam aos Estados Unidos (Braudel, 2009: 554-555). Thomas Cubitt, um empresário de obras públicas que fez fortuna após as guerras napoleônicas, "libertou-se dos subcontratantes que, nesses domínios, eram a velha regra; além disso, cercou-se de uma mão de obra permanente e soube organizar seu próprio crédito" (Braudel, 2009: 555). ${ }^{18} \mathrm{~A}$ independência exibida por esse estilo de empreendedorismo, arremata Braudel, "torna-se o sinal dos novos tempos" (Braudel, 2009: 555). Pela primeira vez, então, estamos diante do empreendedor que controla todo o processo produtivo e se livra de toda intermediação. Weber já havia chegado a essa novidade de forma intuitiva no segundo capítulo de A ética protestante e o espírito do capitalismo, ao se referir a um hipotético manufatureiro inovador de meados do século XIX que "subitamente convulsiona" o estilo tradicional de empreendedorismo de sua época ao se desvencilhar de toda forma de intermediação na condução dos seus negócios. Mas, que relação esta forma autônoma de se conduzir, que data somente do final do século XVIII, ou mesmo do século XIX, pode ter a ver com a Reforma Protestante, ocorrida três séculos antes? Será que este novo estilo de empreendedorismo requereu que os empreendedores passassem a conceber o lucro como um fim em si mesmo, ou, mais do que isto, como um "princípio orientador da vida"? Será, em outras palavras, que o advento desse novo estilo de empreendedorismo requereu mesmo essa mudança específica de mentalidade e, admitindo-se que sim, seria essa mudança um subproduto da Reforma?

A Entwicklungsgeschichte demanda que a resposta seja afirmativa. O trabalho dos historiadores que se detiveram na revolução industrial inglesa, berço do capitalismo moderno, parece apontar, entretanto, na direção oposta. Para além 
de Braudel e Trevor-Roper, Paul Mantoux, em seu trabalho monumental sobre a revolução industrial no século XVIII, chama a atenção para o fato de que, de um modo geral, embora os industriais dessa época tenham se notabilizado pela iniciativa, capacidade de organização e a autonomia acima referida, eles, de um modo geral, "só pensavam em fazer fortuna. Tanto os homens quanto as coisas se reduziam, em suas mãos, a instrumentos úteis para essa finalidade única [...] Muito vaidosos, viviam como grandes senhores, com lacaios, carruagens, suntuosas residências na cidade e no campo" (Mantoux, 1986: 394-395). Conforme se vê, estamos diante de algo bastante distinto do "ascetismo intramundano" que, na visão weberiana, teria que ter desempenhado um papel fundamental nesse processo! Pode-se objetar que o ascetismo intramundano oriundo da Reforma não cumpriu seu papel relevante no século XVIII, mas o fez em uma época anterior. Se é assim, cumpre indagar: em que época? Seria no século XVII? Trevor-Roper mostra que não: o ascetismo intramundano não era um traço da conduta dos empreendedores calvinistas da Europa continental dessa época, pois, para além de não haver diferença entre o estilo de empreendedorismo desses calvinistas e o dos judeus, os calvinistas ricos desfrutavam de uma vida nababesca. Resta, então, o próprio século de Calvino, o século XVI. Mas, conforme mais uma vez aponta Trevor-Roper, nem a Holanda, nem a Escócia, nem Genebra, nem o Palatinado - as quatro sociedades calvinistas óbvias - produziram seus próprios empreendedores (Trevor-Roper, 2007: 42). Assim, a admitir que a emergência de um novo estilo de empreendedorismo incorporado na figura do industrial do final do século XVIII é a grande novidade do capitalismo moderno, está por demonstrar que o surgimento de um novo tipo de mentalidade, supostamente advindo da Reforma, tenha desempenhado um papel importante no surgimento dessa novidade. ${ }^{19}$ Ao polemizar com Sombart, Weber afirma que "nem o que é especificamente novo no sistema econômico moderno, nem o que é especificamente novo na mentalidade econômica moderna são especificamente judaicos." (Weber, 2006: 293-294). Isto é verdade, mas não em razão, como Schluchter quer nos fazer crer, de uma suposta condição de "povo-pária" dos judeus. Por tudo o que foi exposto anteriormente, se o que há de novo no capitalismo moderno não é "especificamente judaico", tampouco é especificamente protestante.

\section{3}

Em seu citado artigo de 2004, Schluchter concede que há algo de errado com a aplicação do conceito de povo-pária ao judaísmo. Este conceito, ele diz, se aplica à situação dos judeus na Idade Média, mas não à Antiguidade. ${ }^{20}$ Weber, ele continua, utilizou-o de forma equivocada ao "construir a situação pária" dos judeus no período que se estende do exílio persa-babilônico (586-538 a. C.) à queda do segundo Templo (70 d. C.). Sendo este o caso, ele conclui, trata-se 
de saber o que justifica esta projeção equivocada: muito mais interessante do que arrolar contra-exemplos que exponham o erro de Weber, ele diz, é saber o que o motivou a construir (ainda que equivocadamente) esta situação pária dos judeus da Antiguidade - "é ver por trás" dessa construção (Schluchter, 2004: 48).

Saibamos, imediatamente, o quê de tão importante Schluchter "viu por trás" do erro de Weber: ao caracterizar os judeus da Antiguidade como um povo-pária, Schluchter diz, Weber "estabelece um pano de fundo contra o qual a missão Paulina aparece de forma clara". Graças a isto, ele pôde ver "nessa missão um ato de liberação de significado histórico-mundial" (Schluchter, 2004: 49). Weber descobriu que Paulo "preservou as criações do Antigo Testamento para o Cristianismo primitivo enquanto este se livrava das imposições dos modos judaicos de pensamento" (Schluchter, 2004: 49). Schluchter cita o próprio Weber para explicar melhor qual foi, segundo este último, o formidável "ato de liberação" propiciado por Paulo:

[...] uma das mais importantes realizações do trabalho missionário de Paulo foi preservar as escrituras sagradas dos judeus para que as mesmas se tornassem as escrituras sagradas dos cristãos, não sem antes, entretanto, purgá-las de todas as prescrições éticas e rituais que mantinham os judeus na sua posição característica de povo pária. A partir de Paulo essas prescrições e rituais não mais se impunham aos cristãos porque haviam sido anuladas pelo Redentor cristão (Weber apud Schluchter, 2004: 49)..$^{21}$

Diante disto, Schluchter dá por esclarecida a importância heurística do conceito de povo-pária: sem o pano de fundo que este conceito propiciou, ele explica, "o ato de liberação [que teria resultado da missão de Paulo] não teria sido tão espetacular" (Schluchter, 2004: 49). Nada surpreendente: a Entwicklungsgeschichte demanda rupturas espetaculares; o conceito de povo-pária pôs em relevo uma (suposta) ruptura espetacular, logo, seu uso está justificado. Mas, será verdade que Paulo transferiu as escrituras sagradas dos judeus para os cristãos da forma como Weber sugeriu? E será verdade que seu trabalho missionário significou o "ato de liberação" que Schluchter, no rastro de Weber (e também de Parsons), tão enfaticamente lhe atribuiu? Receio que, para que a Entwicklungsgeschichte justifique tanto entusiasmo, tenham de ser verdadeiras (ou, pelo menos, não tão manifestamente falsas) as conclusões a que se chega quando se satisfaz suas demandas. Afinal, a prova do pudim está em comê-lo, e não na receita. Provemos, então, do pudim, isto é, averiguemos se a missão de Paulo teve mesmo o "significado histórico-mundial" que Weber lhe atribui.

Inicio pelo mencionado "ato de liberação". Quando Weber afirma que "a partir de Paulo as prescrições e rituais judaicos não mais se impunham aos primeiros cristãos porque haviam sido anuladas pelo Redentor cristão", ele está simplesmente incorrendo em um equívoco. Paulo, de fato, explicava aos gentios, quer fossem os primeiros cristãos ou não, que a salvação da alma não 
dependia da circuncisão, nem de restrições dietárias, nem da observação dos elaborados rituais descritos no Pentateuco etc. Mas este "ato de liberação", como Schluchter o chamou, nada tem a ver com o "Redentor cristão". A ideia de que um não-judeu não precisa se submeter "aos modos de pensamento dos judeus" era um preceito farisaico - não foi uma invenção de Paulo. Era um ensinamento rabínico, antes que cristão, que somente os judeus teriam que observar todo esse conjunto de prescrições e rituais. Para um não-judeu, bastava seguir as sete leis de Noé, pois a observância dessas leis era tudo o que ele necessitava para a salvação da alma. Nesse sentido, Paulo não rompeu com a tradição judaica ao ensinar que um não-judeu está livre das injunções rituais do Antigo Testamento.

No que se refere ao outro feito espetacular que Weber atribui a Paulo, a saber, a transferência das escrituras sagradas judaicas aos cristãos, receio que, nesse particular, Weber tenha se equivocado completamente e Schluchter tenha incorporado este equívoco de forma inteiramente acrítica. Conforme exponho em outro trabalho (Freitas, 2010: esp. cap. 1) a referida transferência foi a culminação de um processo muito mais complicado e laborioso; foi o resultado final de uma longa e sangrenta batalha pela criação da ortodoxia cristã - ou, o que resulta no mesmo, a solução que se obteve, após um enorme esforço, para um problema extremamente espinhoso que, por muito boas razões, dominou todo o período patrístico. Refiro-me ao problema, que Paulo jamais teve que enfrentar, de saber se o Deus dos judeus e o dos cristãos era o mesmo. A feição que o cristianismo assumiu a partir do século IV, e que em larga medida persiste até os nossos dias, tem muito mais a ver com a solução que se deu a este problema do que com o que quer que diga respeito ao trabalho de Paulo. Esta solução foi uma concepção teológica atualmente conhecida como superacionismo, ${ }^{22}$ a qual, embora já tivesse se esboçado na epístola de Barnabás no final do primeiro século, só veio a ser devidamente articulada em meados do século II, cerca de um século após a morte de Paulo.

Embora a descrita posição de Weber a respeito do significado histórico-cultural do trabalho missionário de Paulo possa ser atribuída à sua "orientação comparativa e desenvolvimental", ela me parece muito mais uma reverberação da teologia superacionista, tal como se afigurou no pensamento protestante do século XIX. Os teólogos protestantes do século XIX estavam interessados em saber como pôde o cristianismo, uma "religião universal", surgir a partir do judaísmo, uma "religião étnica", particularista. ${ }^{23}$ A resposta podia ser resumida em uma única palavra: Paulo. No próprio terreno teológico, os termos nos quais essa pergunta está formulada (e, como corolário, a resposta) já são contestados há mais de 40 anos, ${ }^{24}$ mas, ainda assim, Schluchter permanece aceitando esses termos sem reservas - sua "orientação comparativa e desenvolvimental" não o impediu de incorrer neste erro. A exemplo dos teólogos superacionistas, Schluchter vê o trabalho missionário de Paulo como representando o limiar de uma 
transição evolutiva decisiva, ${ }^{25}$ caracterizada pela substituição (e superação) de uma religião étnica por uma religião universal.

Ora, quando definimos uma religião como "universal", em contraposição a outra que definimos como "étnica", ou "cultural" (segundo o próprio Schluchter, Weber definiu o judaísmo como uma religião "cultural”), estamos subentendendo que para a primeira, mas não para a última, o pertencimento a um grupo étnico é uma forma de diferença humana a ser transcendido ou tornado irrelevante. ${ }^{26}$ Será que é legítimo contrapor o cristianismo ao judaísmo no que diz respeito a este ponto? O pensamento protestante do século XIX pressupunha que sim, e Schluchter absorveu este pressuposto de forma acrítica.

Para o pensamento teológico do século XIX a passagem de Paulo havia inequivocamente significado uma ruptura. "Sob a influência do helenismo", escreveu Baur, um dos pilares do pensamento protestante do século XIX, "Paulo deu forma ao Cristianismo"; ele "rompeu completamente as barreiras do Judaísmo e ergueu-se do particularismo do Judaísmo para a ideia universal de Cristianismo" ${ }^{27}$ Harnack, outro gigante do pensamento protestante, arrematou esta resposta cerca de 50 anos mais tarde (Harnack, 1901), ao sustentar que o helenismo continha a semente do universalismo de que o cristianismo precisava para ultrapassar os limites do isolamento nacionalista dos judeus (ver King, 2005: 76). Conforme já sugeri, embora no âmbito da Entwicklungsgeschichte esta solução permanece aceita sem reservas, no interior do próprio pensamento protestante ela começou a ser revista já no início do século XX e, nos dias atuais, é em ampla medida rejeitada. ${ }^{28}$ Isto significa que, quando se trata de discutir as raízes do racionalismo peculiar ao Ocidente, Schluchter mantém-se absorvido em uma concepção teológica protestante do século XIX que o próprio pensamento teológico tem crescentemente rejeitado.

Para mostrar este vínculo entre a Entwicklungsgeschichte e a teologia protestante do século XIX nada melhor que retomar o argumento do próprio Schluchter a respeito das raízes judaicas e cristãs do racionalismo ocidental (Schluchter, 1981). Seguindo a trilha aberta por Weber, Schluchter inicia seu argumento sugerindo que a doutrina profética hebraica foi o ponto de partida do racionalismo ocidental na medida em que significou uma ruptura histórico-cultural sem precedentes:

[A] inovação decisiva do Judaísmo antigo foi a ideia de um Deus Criador transcendente que estabeleceu uma ordem boa à qual todos os seres humanos deveriam se submeter. A partir desse monoteísmo ético, a ação social pôde ser orientada pela noção de uma revolução política e social pretendida por Deus, e o mundo pôde ser compreendido como um fenômeno histórico destinado a ser substituído pela ordem divina (Schluchter, 1981: 152).

Ainda na trilha de Weber, Schluchter argumenta que o povo a quem o "monoteísmo ético" foi originalmente dirigido, dada sua condição de "pária", não foi capaz de completar a ruptura que seus próprios profetas haviam iniciado: 
Entretanto, a transformação da comunidade judaica ligada por juramento no povopária judeu removeu dessa ideia [o monoteísmo ético] sua dinâmica universalista. Ela tornou-se parte de uma moralidade que distinguia os de dentro dos de fora e acreditava-se ser prioritariamente endereçada a um autoproclamado (ascriptive) "povo escolhido" (Schluchter, 1981: 152).

Mas o judaísmo, salienta Schluchter, agora apoiando-se em Parsons, não era tudo o que havia. Havia também, em claro contraste, a cultura intelectual helênica. Esta postulou a existência de uma ordem natural supradivina à qual todos os homens e deuses deveriam igualmente se submeter. Dessa forma, a ação social pôde ser orientada pela ideia de uma ordem natural e justa, universalmente aplicável. Entretanto, ressalva Schluchter, a polis realizou tal ideia [tal 'universalismo cognitivo', nos termos do próprio Schluchter] de uma forma muito limitada porque a vida religiosa permaneceu moldada pela religiosidade politeísta dos mistérios, em detrimento da emergência de deuses "universais" (Schluchter, 1981: 152).

Havia, então, dois problemas requerendo solução: por um lado, a condição "pária" do povo judeu impedia que o mesmo imprimisse ao monoteísmo ético judaico uma "dinâmica universalista"; por outro, a segmentação da religiosidade helênica em deuses locais restringia o alcance do "universalismo cognitivo" helênico. A solução, de acordo com Schluchter, viria justamente com o trabalho de Paulo:

Contra este pano de fundo, a missão de Paulo ganha sua importância decisiva. Ela rompeu completamente os limites atributivos (ascriptive) do monoteísmo ético judaico ao suspender a Lei, com a ajuda do Salvador cristão, e forneceu uma nova base para a religiosidade helênica ao colocar o sofrimento, a morte e a ressurreição do Salvador no contexto desse monoteísmo. Por esta razão Weber considerava a façanha de Paulo de uma importância histórica tremenda. Sem ela, a missão cristã mundial teria sido impossível [...]. Entretanto, para que a missão de Paulo se transformasse em uma missão cristã mundial seria necessário que a congregação cristã se transformasse de uma seita em uma igreja, de uma heterodoxia em uma ortodoxia. O Império Romano forneceu não só o arcabouço político, mas também a inovação institucional crucial, a corporação racional, que se desenvolveu no período imperial (Schluchter, 1981: 152, grifos meus).

Um teólogo protestante do século XIX como Baur haveria de ler tudo isto com entusiasmo (ver nota 27), mas um historiador de boa cepa (de qualquer época) haveria de se espantar com a facilidade com que Schluchter passa por cima de três séculos. Com efeito, na passagem acima Schluchter dá a entender que o cristianismo ao qual o imperador Constantino se converteu já estava pronto, pelo menos no essencial, quando Paulo acabou de realizar seu trabalho, cerca de 300 anos antes. Entretanto, conforme apontou o teólogo sueco Krister Stendahl, há quase 50 anos, Paulo significou muito pouco para o pensamento da Igreja nos primeiros 350 anos de sua história, ${ }^{29}$ e o cristianismo do século IV só se constituiu enquanto tal na medida em que, diferentemente do Paulino, 
se apropriou do passado judaico, transformando a Bíblia Hebraica no "Antigo Testamento" cristão - e, como tal, em uma prefiguração da vinda de Cristo, anunciada pelo "Novo Testamento". Ora, esta visão superacionista está ausente do pensamento Paulino. Para Paulo, o sentido fundamental do aparecimento de Cristo não foi, como asseverava a teologia protestante do século XIX (no rastro de Lutero e de Agostinho), a salvação universal pela fé, mas, sim, a expansão da condição de descendente de Abrahão aos gentios.

Para melhor explicar este ponto vou retomar uma afirmação de Weber através da qual transparece sua má compreensão do sentido histórico-cultural do trabalho de Paulo. Refiro-me à afirmação de que "o trabalho incomparável da missão de Paulo foi sua oferta, aos judeus, de um tremendo alívio, um alívio proporcionado pela consciência de ter escapado ao destino de pária." (Weber, 1965: 260).

Diferentemente do que Weber supunha, Paulo jamais fez qualquer "oferta" aos judeus, mesmo porque o que Paulo tinha, de fato, a oferecer, os judeus já tinham. Eis, em uma palavra, do que se trata: uma linhagem. Com efeito, os judeus já tinham a sua: eram todos descendentes de Abrahão. Aos gentios, a quem Paulo se dirigia, faltava, entretanto, um ancestral comum. Paulo, então, encarregou-se de oferecer-lhes um; o único, aliás, que lhe parecia aceitável: o próprio Abrahão. Os judeus já eram uma raça abrahâmica. Tratava-se, então, de tornar os gentios uma raça abrahâmica também, pois o pertencimento a esta raça era, segundo acreditava Paulo, a única via de acesso à graça divina. Era este, então, o sentido do seu trabalho. Os gentios precisavam aceitar Jesus como o Messias porque, para quem não era judeu, esta era a única via de acesso à linhagem abrahâmica, a qual era, por sua vez, a única via de acesso à salvação. Os judeus, por seu turno, não precisavam compartilhar esta crença, uma vez que já pertenciam, por nascimento, à linhagem de Abrahão.

Nessa perspectiva, Weber acertou ao afirmar que Paulo ofereceu alguma coisa importante a alguém, mas errou no que se refere a o quê foi oferecido e a quem. Não se tratava de liberar os judeus (ou, para dialogar diretamente com Schluchter, os primeiros cristãos também) de o que quer que seja, mas de estender a condição de raça abrahâmica aos gentios. O versículo 3:29 da epístola aos Gálatas deixa isso claro: "E, se sois de Cristo, também sois descendentes de Abrahão, e herdeiros segundo a promessa” (Gal. 3:29). Duas raças abrahâmicas, vivendo lado a lado, até o dia da volta gloriosa de Jesus Cristo, que Paulo supunha iminente: era este o seu Projeto, e não a abolição de diferenças étnicas, ou a superação do judaísmo pelo cristianismo, como supõem Weber e Schluchter. Na perspectiva (farisaica) de Paulo, Deus havia planejado dois caminhos para a salvação, e não um só e, em ambos os caminhos, a descendência (patrilinear) era o que contava. A salvação dos judeus estava condicionada à dos gentios e vice-versa, mas o caminho a ser seguido em cada caso era diferente: o do judeu era a Torá, o do gentio, a fé de Cristo. Ao postular que Deus havia planejado dois 
caminhos para a salvação, ambos condicionados ao pertencimento à linhagem abrahâmica, Paulo não aboliu diferenças étnicas; ao contrário, ele as tornou fundamentais. Para abolir diferenças étnicas, Paulo teria que desconhecer (e não enfatizar) as linhagens bíblicas, como o fez, por exemplo, Marcião, conforme discuto em outro lugar. ${ }^{30}$

Disto resulta que se o conceito weberiano de povo-pária tem algum valor heurístico, continuamos sem saber qual é, pois, certamente, não é o de permitir, como Schluchter assevera, uma melhor compreensão do significado histórico-cultural da missão de Paulo.

\section{4}

Nos parágrafos iniciais deste artigo mencionei que é perfeitamente legítimo o exercício de mostrar que um erro (seja de natureza empírica ou conceitual) pode conduzir a uma contribuição teórica relevante - foi assim com Galileu, cujo erro de supor que a Lua não tinha influência sobre as marés resultou em contribuições importantes, se Popper estiver correto em sua avaliação. Receio, entretanto, que o erro de Weber ao caracterizar os judeus da Antiguidade (como também os da Idade Média) como um "povo-pária" só tenha conduzido a mais erros, como o de atribuir equivocadamente ao trabalho missionário de Paulo uma ruptura de importância decisiva para o desenvolvimento do racionalismo ocidental. Em "A psicologia social das religiões mundiais", Weber nos convida a procurar por "imagens mundiais" que tenham funcionado como "agulheiros" (Weber, 1974: 323); ${ }^{31}$ em outras palavras, por pontos de inflexão responsáveis por conduzir o desenvolvimento histórico a direções imprevistas. Pontos de inflexão de tal natureza, certamente, existem, mas a pregação de Paulo não foi um deles; não, pelo menos, do modo como Weber sugeriu. É certo que nos séculos posteriores o pensamento Paulino foi gradativamente reconstruído, pelo pensamento cristão, como uma ruptura decisiva com o judaísmo, e que esta reconstrução, ela própria, pode ter sido uma dessas "imagens mundiais" ou pontos de inflexão que Weber nos convida a procurar. Mas, isto, Schluchter não viu, não obstante estar de posse das poderosas lentes oferecidas pela Entwicklungsgeschichte. Por outro lado, historiadores como Burton L. Mack (1996) e John Dominic Crossan (1999), que nada sabem de Entwicklungsgeschichte, puderam ver que toda essa importância histórica que nos habituamos a atribuir ao trabalho missionário de Paulo é, ela própria, uma autoimagem, uma construção retrospectiva realizada pelo próprio pensamento cristão. Isto mostra que nada há de intrinsecamente meritório ou de indispensável em relação à Entwicklungsgeschichte. Esta última é, tanto quanto a perspectiva evolucionista contra a qual se insurge, apenas uma matriz para a produção de conjecturas. Nenhuma dessas matrizes pode garantir, a priori, o que de fato importa: a validade e o alcance das conjecturas 
que se produzem a partir delas. Daí que não temos por que preferir uma à outra até que conheçamos as conjecturas geradas a partir de cada uma e possamos averiguar sua validade e seu alcance, da mesma forma que não podemos decidir entre dois pudins até que provemos cada um. Ao proceder desta forma, somos forçados a admitir que a perspectiva "desenvolvimental" de Weber encerra erros bizarros no que diz respeito tanto à identificação das características definidoras do judaísmo quanto à interpretação do significado histórico-cultural do trabalho de Paulo. Por outro lado, em face do que foi exposto anteriormente, é possível até mesmo sugerir que as lentes por meio das quais o próprio Weber enxergou a importância "desenvolvimental" da missão de Paulo, ou do advento do cristianismo de um modo geral, não foram fornecidas pela "história desenvolvimental", pela Entwicklungsgeschichte, como Schluchter sugeriu, mas por uma perspectiva "teórico-conceitual" cujas credenciais são bem menos formidáveis, a saber, a teologia superacionista cristã, tal como se afigurou no pensamento protestante do século XIX, e tem sido crescentemente rejeitada no interior do próprio pensamento teológico cristão.

Artigo recebido para publicação em dezembro de 2010.

Renan Springer de Freitas é professor titular de Sociologia na Universidade Federal de Minas Gerais (UFMG) e Bolsista de Produtividade em Pesquisa do Conselho Nacional de Desenvolvimento Científico e Tecnológico (CNPq). Atualmente é membro do Conselho Editorial do periódico Philosophy of the Social Sciences. Suas principais áreas de interesse são: sociologia do conhecimento, sociologia da ciência, epistemologia e sociologia da religião. É autor de Sociologia do conhecimento, pragmatismo e pensamento evolutivo (2003) e Judaísmo, racionalismo e teologia cristã da superação: um diálogo com Max Weber (2010). 


\section{NOTAS}

1 Veja-se, em ordem cronólogica: Toni Oelsner (1962); Hans Liebeschütz (1964); Efraim Shmueli, (1968); Werner J. Cahnman (1974); Arnaldo Momigliano (1980); Gary Abraham (1988); e David Nirenberg (2003).

2 Retorno a este argumento na seção 3.

3 Na página 199 deste livro se lê: “Dificilmente se conhecerá outra concepção weberiana que tem sido tão duramente criticada quanto esta. E por boas razões. Este conceito é historicamente inexato e não está livre de conotações ideológicas".

4 Aproveito para esclarecer que mantive o termo original Entwicklungsgeschichte no subtítulo deste trabalho apenas para evitar que um barbarismo como "história desenvolvimental" aparecesse no subtítulo.

5 Por uma questão de justiça devo mencionar que cheguei a esta passagem por meio do artigo "História e ciências sociais: notas sobre o uso da lógica, teorização e crítica" (Reis, 2001). Que Bruno Reis, em uma das raras e boas discussões a respeito da relação entre história e ciências sociais produzidas no Brasil recentemente, tenha reproduzido uma passagem como esta com admiração é um claro indicador de que estou me contrapondo a uma perspectiva que desfruta de prestígio no meio acadêmico brasileiro.

6 O capítulo XIII do referido livro é composto de duas seções, cujos títulos são "The development of ritualistic segregation" e "The dualism of in-group and out-group morality".

7 Nesse ponto, como em muitos outros da presente discussão, não faltará quem argumente que o conceito de povo-pária é uma construção típico-ideal, não se prestando, por essa razão, à refutação através de exemplos históricos. Para rebater esse argumento não posso fazer melhor que reproduzir a seguinte passagem do livro o fetichismo do conceito, de Luís de Gusmão (2012: 277): “não se diga, por favor, que Weber opera com 'tipos ideais' e esses, enquanto idealizações conceituais do fenomênico, não correspondem a nada encontrado no âmbito do socialmente real. Essa defesa é de fato muito ruim, e revela apenas, além 
da preocupação obscurantista em subtrair uma sociologia empírica da possibilidade mesma do desmentido factual, uma grande confusão filosófica: como bem sabe qualquer pessoa minimamente familiarizada com a moderna reflexão epistemológica, os enunciados ou sistemas de enunciados, e não os conceitos isolados, é que são levados ao famoso tribunal da experiência. Em A Lógica da Pesquisa Científica, Popper já mencionava [...] que a ciência não é um sistema de conceitos, mas, antes, um sistema de enunciados. Em 'Two Dogmas of Empiricism', Quine aponta na mesmíssima direção, embora vá um pouco mais longe com o seu holismo metodológico algo extremado: 'os enunciados, ao invés dos termos, foram, desde Russell, admitidos como a unidade a ser levada em conta na crítica empírica'. Não é necessário prosseguir com essas citações: inexistem maiores divergências entre os filósofos da ciência acerca desse ponto: os enunciados, e não os conceitos, é que são empiricamente testados. Com efeito, não faz muito sentido, por exemplo, perguntar se os conceitos de capitalismo racional e dominação legal são verdadeiros ou falsos à luz da investigação empírica, mas faz todo sentido formular essa mesmíssima pergunta quando se trata de enunciados que asseguram a efetiva presença, numa determinada sociedade, da dominação política legal e da economia capitalista racional, na acepção weberiana desses termos. Os exemplos poderiam facilmente ser multiplicados. Conclusão inescapável: na realidade, todos os tipos ideais weberianos são, desde que inseridos em enunciados, passíveis sim de controle empírico".

8 Os Concílios de Vannes (465), Agda (506), Epona (535), Clermont (535) e Mâcon (583), para citar apenas alguns, não só proibiram expressamente aos cristãos de comer com os judeus como também se insurgiram contra os casamentos mistos. E a lei canônica, fundamento de todas as resoluções jurídicas dos Estados eclesiásticos da Idade Média, uma vez introduzida em Portugal - durante o reinado de D. Afonso II (1211-1223) - proibiu o contato de cristãos com os judeus, procurando o mais possível isolar uns dos outros.

9 Em General economic history (Weber, 2003: 359) está escrito que "o que distinguiu, de forma decisiva, os judeus dos povos-hospedeiros cristãos foi a impossibilidade dos primeiros de manter commercium e conubium com os últimos". Weber 
não teria feito uma afirmação desta natureza se tivesse tido contato com a literatura conciliar. Ele, de fato, ignorava o que se passava entre judeus e cristãos na Antiguidade e na Idade Média. Para uma descrição a respeito deste convívio, ver, por exemplo, Poliakov (1979: 24; 1961: 14).

10 Para uma visão do período Aaronita e o rompimento que este período significou tanto com o período deuteronômico quanto com o dos Levitas, ver Rivkin (1971).

11 Argumentos nesta mesma direção podem ser encontrados nos trabalhos de Nirenberg (2002), Brundage (1988), e, principalmente, Friedman (1987).

12 Weber sugere isto não apenas na passagem reproduzida acima como também nos parágrafos finais de Ancient Judaism.

13 Dentre as restrições impostas aos judeus e cristãos por este pacto, destacam-se: o pagamento de impostos especiais, a proibição de construir igrejas e sinagogas, de carregar armas e andar a cavalo e a obrigatoriedade de usar roupas que os distinguissem. Ver Scheindlin (2004: 115).

14 Para uma excelente discussão a respeito desse ponto veja-se, Gusmão (2012), especialmente o capítulo 1.

15 Como explica Kevin Carr: "A Confissão de Westminster (1647) foi o resultado de mais de um século de reflexão Protestante sobre a verdade bíblica. Ela foi um dos muitos documentos produzidos pela Assembleia de Westminster ocorrida em Londres durante o Mandado do Parlamento de 1643 a 1652, quando ela foi oficialmente dissolvida. Nas palavras de Jogn H. Leigth, a Confissão e seus Catecismos 'trouxe a um clímax de um modo grandioso e monumental um dos maiores períodos teológicos da história da Igreja cristã'" (Carr, 2009: 2).

16 "O livro-caixa genuíno surgiu pela primeira vez na Itália medieval, e muito tardiamente, no século XVI, um funcionário alemão foi até Veneza para assegurar seus conhecimentos nessa arte" (Weber, 2003: 224).

17 Ancorando-me no trabalho de Trevor-Hoper, desenvolvi este ponto em meu Judaísmo, racionalismo e teologia cristã da superação (Freitas, 2010: cap. 4).

18 Braudel, aqui, baseia-se inteiramente na citada obra de Peter Mathias. 
19 Isto não quer dizer que a Reforma não tivesse efeito sobre o modo de condução dos negócios ou da vida de um modo geral. "Seria absurdo negá-lo", como diz o próprio Braudel. "Para começar, a Reforma cria a coesão dos países do Norte. Ergue-os unidos contra os países do Sul. Não é pouco" (Braudel, 2009: 509).

$20 \mathrm{Na}$ verdade, nem à situação da Idade Média ele se aplica, mas ignoremos isto para efeito de raciocínio.

21 Traduzi livremente este trecho (do alemão para o inglês) de Schluchter. A versão do Ancient Judaism (traduzido do alemão por Hans Gerth e Don Martindale) é ligeiramente diferente.

22 "Superacionismo" (traduzido de "supersessionism") é a visão de que o sacrifício redentor de Jesus tornou o judaísmo obsoleto porque universalizou o acesso à graça divina outrora restrita ao povo de Israel. De acordo com esta visão, o verdadeiro assunto do "Antigo Testamento" (que é "antigo" não em um sentido cronológico, mas no sentido de que foi superado pelo "Novo Testamento") é a chegada redentora de Cristo, e os judeus não foram capazes de perceber isto.

23 Esta questão foi originalmente formulada pelo teólogo luterano Ferdinand C. Baur (1792-1860). Ver Baur (2003) e The Church history of the first three centuries (Baur, 1878-79 [185363] apud Hodge, 2007: 6).

24 Já na década de 1960 o teólogo sueco Krister Stendahl colocava em questão a tese de que Paulo seria um ponto de transição entre o judaísmo (como religião étnica) e o cristianismo (como religião universal) ao afirmar: "Embora Paulo estivesse interessado em incluir os gentios na comunidade messiânca, seus escritos são hoje lidos como respostas para a questão de como o homem pode assegurar a sua salvação tendo em vista sua condição intrisecamente pecaminosa" ("his statements are now read as answers to the quest for assurance about man's salvation out of a common human predicament") (Stendahl, 1963: 206).

25 Certa vez, ao submeter um artigo para publicação, fui duramente repreendido pelo avaliador por usar o "pejorativo" e "desrespeitoso" termo "evolutivo" ao parafrasear os pensamentos de Weber e Schluchter. Fui aconselhado a usar o termo "desenvolvimental", em vez de "evolutivo". A que ponto chegamos! 
26 Devo a formulação deste ponto à leitura do artigo "Rethinking the relevance of race for early Christian self-definition" (Buell, 2001).

27 "[Paulo] rompeu completamente as barreiras do Judaísmo e ergueu, a partir do particularismo judaico, a ideia universal do Cristianismo" (Baur, 1853, vol.1: 47 apud Hodge, 2007: 6). Schluchter diz exatamente a mesma coisa ao afirmar que Paulo "rompeu completamente os limites atributivos do monoteísmo ético judaico ao suspender a Lei, com a ajuda do Salvador cristão" (Schluchter, 1981:152).

28 Desenvolvo este ponto em Freitas (2010: cap. 3). De qualquer forma, ver, a respeito, Hagner (1993), Dunn (1991), e, principalmente, o trabalho do teólogo protestante Lloyd Gaston (1987).

29 "Permanece um enigma o fato de Paulo ter representado relativamente tão pouco para o pensamento da Igreja nos primeiros 350 anos de sua história" (Stendahl, 1963: 203). Este trabalho de Stendhal, escrito em 1963, é um divisor de águas na discussão a respeito da importância histórica e teológica da pregação de Paulo. Ver, por exemplo, Hagner (1993).

30 Desenvolvo tudo isto em Freitas (2010: cap. 3).

31 Neste texto o termo que aparece não é "agulheiros", mas "manobreiros". O leitor escolhe o que achar melhor. O termo em inglês de onde esta palavra foi traduzida é "switchmen". 


\section{REFERÊNCIAS BIBLIOGRÁFICAS}

Abraham, Gary. Max Weber on "Jewish rationalism" and the Jewish Question. International Journal of Politics, Culture and Society, 1988, 1/3, p. 358-391.

Adelman, Janet. Her father's blood: race, conversion, and nation in The Merchant of Venice. Representations, 2003, 81, p. 4-30.

Baur, Ferdinand C. Paul, the apostle of Jesus Christ: his life and works, his Epistles and teachings. Peabody, MA: Hendrickson Publishers, [1873-75] 2003. Edição original em alemão de 1845. (2 vol. em 1)

Braudel, Fernand. Civilização material, economia e capitalismo: sec. XV-XVIII. São Paulo: Martins Fontes, 2009. (vol. II: Os jogos das trocas)

Brundage, James A. Intermarriage between Christian and Jews in Medieval Canon Law. Jewish History, 1988, 3, p. 25-40.

Buell, Denise Kimber. Rethinking the relevance of race for early Christian self-definition. The Harvard Theological Review, 2001, 94/4, p. 449-476.

Cahnman, Werner J. Pariahs, strangers and court-Jews: a conceptual clarification. Sociological Analysis, 1974, 35/3, p.155-166.

Carr, Kevin C. Covenant theology in The Westminster Confession of Faith. Dissertação de Mestrado. Puritan Reformed Theological Seminary, 2009.

Cohen, Jere. Rational capitalism in Renaissance Italy. The American Journal of Sociology, 1980, 85/6, p. 1340-1355.

Crossan, John D. The birth of Christianity. Nova York: Harper Collins, 1999.

Dunn, James D. G. From Baur to Sanders. In: The parting of the ways: between Christianity and Judaism and their significance for the character of Christianity. Londres: SCM Press, 1991. Feyerabend, Paul. Against method. 3.ed. Londres/Nova York: Verso, [1975] 1993.

Freitas, Renan Springer de. Judaísmo, racionalismo e teologia cristã da superação: um diálogo com Max Weber. Belo Horizonte: Fino Traço, 2010. 
Friedman, Jerome. Jewish conversion, the Spanish pure blood laws and reformation: a revisionist view of racial and religious anti-semitism. Sixteenth Century Journal, 1987, 18/1, p. 3-30.

Gaston, Lloyd. Paul and the Torah. Vancouver: University of British Columbia Press, 1987.

Graf, Friedrich. The German theological sources and Protestant Church politics. In: Lehmann, Hartmut \& Roth, Guenther (orgs.). Weber's protestant ethic, origins, evidence, contexts. Cambridge: Cambridge University Press, 1993.

Gusmão, Luís de. O fetichismo do conceito: limites do conhecimento teórico na investigação social. Rio de Janeiro: Topbooks, 2012.

Hagner, Donald. Paul and Judaism: the Jewish matrix of early Christianity: issues in the current debate. Bulletin for Biblical Research, 1993, 3, p. 111-130.

Harnack, Adolf. What is Christianity? Lectures delivered in the University of Berlin during the Winter Term, 1899-1900. Nova York/ Londres: G. P. Putnam's Sons/Williams and Norgate, 1901.

Hodge, Caroline J. If sons, then heirs: a study of kinship and ethnicity in the letters of Paul. Nova York: Oxford University Press, 2007.

Holton, Robert J. Max Weber, "rational capitalism", and Renaissance Italy: a critique of Cohen. American Journal of Sociology, 1983, 89/1, p. 166-80.

King, Karen L. What is Gnosticism?. Cambridge: The Belknap Press of Harvard University Press, 2005.

Lehmann, Hartmut. Ascetic Protestantism and economic rationalism: Max Weber revisited after two generations. The Harvard Theological Review, 1987, 80/3, p. 307-320.

Liebeschütz, Hans. Max Weber's historical interpretation of Judaism. Leo Baeck Institute Yearbook, 1964, 9/1, p. 41-68.

Mack, Burton L. Who wrote the New Testament? The making of the Christian myth. San Francisco: Harper, 1996.

MacKinnon, Malcolm H. Part I: Calvinism and the infallible assurance of grace: The Weber thesis reconsidered. The British Journal of Sociology, 1988, 39/2, p. 143-147. 
Momigliano, Arnaldo. A note on Max Weber's definition of Judaism as a pariah religion. History and Theory, 1980, 19/3, p. 313-318.

Mantoux, Paul. A revolução industrial no século XVIII. São Paulo: Hucitec, [1906] 1986.

Nirenberg, David. The birth of the pariah: Jews, Christian dualism, and social science. Social Research, 2003, 70/1, p. 201-236.

Conversion, sex, and segregation: Jews and Christians in medieval Spain. The American Historical Review, 2002, 17/4, p. 1065-1093.

Oelsner, Toni. The place of the Jews in economic history as viewed by German scholars: a critical-comparative analysis. Leo Baeck Institute Yearbook, 1962, 7/1, p. 183-212.

Poliakov, Léon. De Cristo aos judeus da corte. São Paulo: Perspectiva, [1955] 1979.

. De Maomé aos marranos. São Paulo: Perspectiva, 1961.

Popper, Karl. Objective knowledge. Oxford: Clarendon Press, [1972] 1992.

Reis, Bruno. História e ciências sociais: notas sobre o uso da lógica, teorização e crítica. Crítica: Revista de Filosofia, 2001. Disponível em <http://criticanarede.com/html/fil_histcienciass.html>. Acesso em 15 jun. 2012.

Rivkin, Ellis. The shaping of Jewish history. Nova York: Charles Scribner's Son, 1971.

Scheindlin, Raymond P. História ilustrada do povo judeu. Rio de Janeiro: Ediouro, 2004.

Schluchter, Wolfgang. The rise of Western rationalism: Max Weber's developmental history. Berkeley: University of California Press, 1981.

Rationalism, religion and domination: a Weberian perspective. Berkeley: University of Columbia Press, 1989.

. The approach of Max Weber's sociology of religion as exemplified in his study of ancient Judaism. Archives de Sciences Sociales des Religions, 2004, 127, p. 33-56.

Shmueli, Efraim. The "pariah-people" and its "charismatic leadership": a revaluation of Max Weber's "Ancient Judaism". 
Proceedings of the American Academy for Jewish Research, 1968, 36, p. 167-247.

Stendahl, Krister. The apostle Paul and the introspective conscience of the West. Harvard Theological Review, 1963, 56, p. 199-215.

Trevor-Roper, Hugh. A crise do século XVII: religião, a Reforma e mudança social. Rio de Janeiro: Topbooks, [1967] 2007.

Weber, Max. Ancient Judaism. Glencoe, IL: The Free Press, 1952.

The sociology of religion. Londres: Methuen \& Co Ltd, [1922] 1965.

A psicologia social das religiões mundiais. In: Gerth, Hans \& Mills, Charles (orgs.). Ensaios de sociologia. 3.ed. Rio de Janeiro: Zahar, 1974.

. General economic history. 8. ed. Londres: Transaction Publishers, 2003.

Sociologias das religiões. Tradução de Paulo Osório de Castro. Lisboa: Relógio d’Água, 2006. 


\begin{abstract}
Palavras-chave:
Sociologia da religião;

Max Weber;

Racionalismo ocidental; Judaísmo; Protestantismo.
\end{abstract}

\begin{abstract}
Resumo:
A ideia de que erros bizarros podem conduzir a grandes acertos não é estranha à história da ciência. Este artigo examina o esforço realizado por Wolfgang Schluchter no sentido de mostrar que um determinado erro de Max Weber conduziu a um grande acerto - em razão de ter sido produzido nos marcos de uma perspectiva metateórica que conduz erros a acertos, a perspectiva "histórico-desenvolvimental" (Entwicklungsgeschichte). O erro: aplicar o conceito de "povo-pária" aos judeus da Antiguidade. Argumento de Schluchter: os historiadores mostraram que o conceito de "povo-pária" não se aplica aos judeus da Antiguidade, mas, não obstante, vale a pena insistir nesse erro porque ele conduz a um grande acerto: mostrar a importância da ruptura efetuada pelas missões Paulinas (com o particularismo judaico) para o desenvolvimento do racionalismo ocidental. Argumento do artigo: isto que Schluchter considera o grande acerto é apenas uma reverberação do pensamento teológico protestante do século XIX.
\end{abstract}

\section{Keywords: Abstract:}

Sociology of religion;

Max Weber;

Western rationalism; Jewish; Protestantism.
The view that bizarre mistakes can lead to great achievements is not unfamiliar to the historians of science. This paper examines Wolfgang Schluchter's efforts towards showing that a certain mistake by Max Weber ended up by leading to a great achievement - on account of coming up out of a meta-theoretical perspective which allegedly turns mistakes into achievements, namely, so-called historical-developmental perspective (Entwicklungsgeschichte). The mistake: applying the concept of "pariah-people" to the Jews of Antiquity. Schluchter's argument: the historians have shown that the concept of "pariah-people" does not apply to the Jews of Antiquity but even though it is worthwhile to insist in this mistake because it has led Weber to a great achievement: showing the importance of the rupture accomplished by Pauline missions (against Jewish particularism) in the rise of Western rationalism. Argument of this paper: what Schluchter considers to be one of Weber's greatest achievements is just another mistake; a reverberation of the protestant theological thinking of the XIXth century. 